\title{
KAJIAN PENEGAKAN HUKUM TERHADAP TINDAKAN PENGANIAYAAN HEWAN DAN EKSPLOITASI SATWA LANGKA
}

\author{
Stefany Ismantara ${ }^{1}$, Raden Ajeng Diah Puspa Sari ${ }^{2}$, Cecilia Elvira ${ }^{3}$, \\ Prof. Dr. Jeane Netlje Sally ${ }^{4}$
}

\author{
${ }^{1}$ Fakultas Hukum, Universitas Tarumanagara Jakarta \\ Email: stefanism0404@gmail.com \\ ${ }^{2}$ Fakultas Hukum, Universitas Tarumanagara Jakarta \\ Email: radiahpuspa@gmail.com \\ ${ }^{3}$ Fakultas Hukum, Universitas Tarumanagara Jakarta \\ Email: ceciliaelvira2114@gmail.com \\ ${ }^{4}$ Fakultas Hukum, Universitas Tarumangara Jakarta \\ Email: jeanes@fh.untar.ac.id
}

\begin{abstract}
Animal cruelty is an immoral crime that usurps animal rights, while exploitation of endangered animals is an act that has the potential to kill biodiversity in its country. The purpose of this article is to evaluate law enforcement against animal cruelty in Indonesia and its obstacles. The methodology used in this research is normative legal research which focused on secondary data approach. Although laws that regulate these criminal acts exist, such as Article 302 Criminal Code which explains the prohibition of actions that are detrimental to animal health, Law 5/1990 concerning conservation of the living natural resources and its ecosystem, added with Law18/2009 concerning husbandry and animal health, criminal cases regarding maltreatment and exploitation of circus animals, also abuse to killing pets and hunting of protected wildlife are still rampant. This could happen because of weak law enforcement that prevents deterrence. Criminal sanctions given to the perpetrators of animal cruelty are considered very light and justice for animal welfare is almost non-existent. Factors that cause weak law enforcement are unsupportive constitutions, law enforcers, law facilities, its country community, and the legal culture factor. In order to overcome this matter, formulation of appropriate law to ensure legal certainty, a supportive constitution, education about biodiversity to the community, a proper surveillance system, assertiveness in law enforcement officers, and availability of adequate facilities are needed.
\end{abstract}

Key Words : Law enforcement, Animal cruelty, Exploitation of endangered animals

\begin{abstract}
ABSTRAK
Penganiayaan terhadap hewan merupakan suatu tindak kejahatan asusila yang merampas hak hewan. Sementara eksploitasi satwa langka adalah suatu tindakan yang berpotensi mematikan keanekaragaman hayati dalam negara. Penulisan ini bertujuan untuk mengetahui bagaimana penegakan hukum terhadap pelaku penganiayaan hewan dan eksploitasi satwa langka di Indonesia, serta faktor penghambatnya. Metode penelitian yang digunakan untuk menyusun artikel ini adalah metode penelitian hukum normatif yang berfokus pengumpulan data sekunder. Walau sudah ada peraturan perundang-undangan yang mengatur tindak pidana tersebut, seperti pada Pasal 302 KUHP yang membahas mengenai larangan perbuatan yang merugikan kesehatan hewan, UU 5/1990 tentang Konservasi Sumber Daya Alam Hayati dan Ekosistemnya, ditambah dengan UU 18/2009 tentang Peternakan dan Kesehatan Hewan, kasus-kasus seperti penganiayaan dan eksploitasi hewan sirkus, juga penganiayaan hingga pembunuhan terhadap hewan peliharaan dan perburuan satwa liar yang dilindungi masih saja marak terjadi. Hal ini diakibatkan oleh penegakan hukum yang lemah sehingga efek jera gagal dimunculkan. Sanksi pidana yang diberikan kepada pelaku tindak pidana dinilai sangat ringan dan eksistensi keadilan bagi kesejahteraan hewan hampir tidak ada. Penegakan hukum yang lemah disebabkan oleh faktor Undang-Undang, penegak hukum, sarana dan fasilitas, faktor masyarakat, dan faktor budaya hukum. Dibutuhkan perumusan suatu aturan yang menjamin kepastian hukum untuk mendongkrak efektivitas hukum, penyuluhan masyarakat, sistem pengawasan yang memadai, ketegasan dari para aparat penegak hukum, dan ketersediaan fasilitas dan sarana yang memadai.
\end{abstract}

Kata Kunci : Penegakan hukum, Penganiayaan hewan, Eksploitasi satwa langka 


\section{PENDAHULUAN}

\section{Latar Belakang}

Penganiayaan terhadap hewan bukanlah topik yang asing didengar dengan berbagai kasus yang tersebar di media cetak maupun elektronik di Indonesia. Tindakan penganiayaan hewan termasuk dalam kategori kejahatan asusila. Kejahatan asusila merupakan perbuatan yang melanggar norma-norma yang telah ditetapkan. Kejahatan asusila ini tidak semerta-merta dilakukan kepada manusia saja, tetapi juga dapat dilakukan kepada binatang. Manusia yang diberkahi akal sehat dan budi pekerti seharusnya dapat membela hak-hak hewan sebagai sesama makhluk hidup. Penganiayaan terhadap hewan merupakan kekerasan yang dengan sengaja ataupun tidak sengaja dilakukan oleh manusia untuk mencari keuntungan dan kesenangan pribadi.

Banyak tempat wisata di Indonesia yang masih menggunakan tenaga hewan sebagai hiburan bagi para wisatawan. Salah satu contohnya adalah beberapa Hotel dan Resort yang ada di Bali, di mana tersedia Dolphin pool yang menawarkan pertunjukkan atau atraksi lumba-lumba terlatih yang menarik perhatian wisatawan (Fanny, 2018). Salah satu contoh eksploitasi lumba-lumba yang dijadikan sebagai hewan atraksi yaitu yang dilakukan oleh PT. Wersut Seguni Indonesia (WSI), yang berperan sebagai lembaga konservasi namun mendapatkan izin peragaan satwa. Hal ini memprihatinkan karena aktivitas lembaga konservasi seharusnya dilatarbelakangi oleh rasa kepedulian terhadap kesejahteraan hewan, sementara larangan sirkus keliling itu sendiri telah ditentukan melalui surat yang dikeluarkan oleh Dirjen PHKA Nomor 5 297/IV-KKH/2013 (Claudia, 2018).

Jika lembaga konservasi yang ditujukan untuk melindungi kesejahteraan hewan itu sendiri memberi contoh yang berkontradiksi dengan visinya sebagai pelindung sumber daya alam hayati, bagaimana pemerintah dapat berekspektasi tinggi terhadap kesadaran masyarakat dan organisasi lainnya mengenai perihal tersebut? Izin untuk melakukan sirkus lumba-lumba keliling itu kemudian tak diperpanjang lagi oleh Kementerian Lingkungan Hidup dan Kehutanan (KLHK) mulai 5 Februari 2020, namun karena kelalaian dari aparat penegak hukum, masih saja ada korporasi yang lolos setelah melakukan praktek yang merupakan bentuk penganiayaan dan eksploitasi satwa tersebut.

Wisatawan dan konsumen hanya dapat menikmati jasa hiburan yang telah disediakan oleh pihak tempat penginapan. Hanya sedikit yang menaruh kepedulian mengenai pelatihan dibalik kecakapan para binatang tersebut dalam melakukan atraksinya. Binatang-binatang tersebut dipaksa untuk tinggal jauh dari lingkungan hidup mereka yang seharusnya. Mereka harus hidup dalam sebuah kolam berukuran kecil dengan kandungan klorin yang membahayakan kesehatan, terutama kesehatan mata hewan tersebut. Hal ini merupakan pelanggaran terhadap hak asasi hewan. Sementara hak asasi hewan seharusnya telah terlindungi melalui UU 18/2009 tentang Peternakan dan Kesehatan Hewan secara keseluruhan, dan melalui Pasal 66 ayat 2 secara spesifik, ditambah dengan Pasal 302 KUHP mengenai penganiayaan dan pembunuhan hewan. Peraturan-peraturan yang ada tampaknya kurang memadai untuk menarik kesimpulan bahwa pemanfaatan hewan sebagai hewan atraksi tanpa memperhatikan aspek-aspek kesejahteraannya adalah suatu tindak kekejian terhadap hewan. Hal ini dibuktikan dengan masih diperlukannya tambahan larangan dan pencabutan izin sirkus keliling bertahun-tahun setelahnya.

Contoh tindak penganiayaan terhadap hewan lainnya adalah kasus penculikan dan penganiayaan hewan di Jalan Dumpit, Jatiuwung, Kota Tangerang yang menyebabkan kematian seekor anjing (Naufal, 2021). Anjing tersebut dibawa dengan cara diseret oleh sepeda motor yang dikendarai pelaku dengan media tali yang menghubungkan si hewan dengan sepeda motor tersebut sepanjang perjalanan dari Curug sampai ke wilayah Kota Tanggerang. Sang pemilik anjing yang mencoba melaporkan kejadian tersebut ditolak oleh pihak kepolisian dengan alasan pelapor tidak mempunyai bukti kepemilikan yang sah dan pemilik hanya dapat menunjukan bukti berupa foto bersama anjingnya. Pada saat kematiannya, anjing tersebut sudah terseret sampai ke wilayah 
Kota Tangerang, sehingga sang pemilik harus membuat laporan ke Polresta Tangerang Selatan. Sang pemilik mendapatkan penolakan untuk yang kedua kalinya dengan alasan yang sama, yakni tidak adanya bukti kepemilikan anjing. Kasus ini menimbulkan keraguan atas tujuan dari perumusan Pasal 302 KUHP dan UU No.18 Tahun 2009 yang seharusnya bertujuan untuk melindungi hak hewan, bukan hanya hak manusia sebagai pemilik dari hewan tersebut. Pelaku seharusnya dapat dijerat pelanggaran Pasal 302 KUHP tentang penganiayaan dan pembunuhan hewan. Namun pada kenyataannya, bagi para penegak hukum, bukti kepemilikan lebih cocok menjadi prioritas utama dibandingkan penegakan keadilan bagi anjing yang sudah kehilangan nyawanya tersebut.

World Wide Fund for Nature (WWF) Indonesia mencatat tingginya permintaan terhadap hewan langka terutama bagian-bagian tubuhnya (Sianturi, 2018). Tingginya permintaan akan mengakibatkan kenaikan penawaran. Hal inilah yang menyebabkan maraknya perdagangan terhadap hewan langka dan bagian-bagian tubuhnya. WWF Indonesia mencatat ada sekitar 8 ton gading gajah yang beredar di daerah Sumatera, 100 ekor orangutan yang diselundupkan ke luar negeri setiap tahunnya, dan sebanyak 2000 kukang diperjualbelikan di daerah Jawa juga diselundupkan ke luar negeri. Beberapa tahun terakhir, tercatat sebanyak 74 ekor orang utan yang diperjualbelikan secara online. Terdapat pula 15 ekor harimau yang diperjualbelikan melalui media sosial facebook (Sianturi, 2018).

Pada 2 Mei 2019 lalu telah ditangkap pelaku perdagangan satwa langka melalui media sosial facebook. Barang bukti yang didapatkan antara lain tiga anak Elang Brontok, satu Kucing Akar, dan tiga anak Lutung Emas. Pelanggaran tersebut telah memenuhi unsur pasal 21 ayat (2) huruf a jo. Pasal 40 ayat (2) UU 5/1990 tentang Konservasi Sumber Daya Alam Hayati dan Ekosistemnya. Dalam ketentuan pasal tersebut dijelaskan bahwa pelaku pelanggaran dapat dikenakan sanksi pidana penjara maksimal lima tahun dan denda Rp100.000.000,00. Sanksi yang diatur dalam pasal tersebut sudah tergolong cukup ringan dibandingkan dengan kerugian yang ditimbulkan. Namun, Hakim pada akhirnya hanya menjatuhkan vonis pidana penjara selama satu tahun enam bulan dan denda sebesar lima puluh juta rupiah. Hukuman tersebut lebih ringan enam bulan dari tuntutan Jaksa Penuntut Umum (Evan, 2019). Peristiwa ini menghasilkan pertanyaan mengenai esensi dari perumusan UU 5/1990 yang pada hakikatnya bertujuan untuk mewujudkan pengelolaan dan pemanfaatan sumber daya alam hayati secara lestari agar tidak menimbulkan kekacauan ekosistem. Kasus tersebut hanya merupakan contoh dari sekian banyak kasus eksploitasi satwa langka yang berakhir tanpa terpenuhinya keadilan bagi para binatang tersebut.

Perilaku penganiayaan hewan dan eksploitasi satwa langka yang dibiarkan dapat menipiskan moralitas bangsa yang menimbulkan suatu kebiasaan buruk dan sifat kejam pada manusia. Eksploitasi satwa langka juga mengikis keanekaragaman hayati dan berpotensi menghancurkan keseimbangan ekosistem yang dapat membahayakan lingkungan hidup. Penegakan hukum yang lemah membuat masyarakat memandang remeh dan tidak mempedulikan kesejahteraan hewan sebagai pendamping kehidupan manusia. Dalam hal ini perlu diberlakukan hukum pidana yang tegas bagi pelaku penganiayaan hewan dan eksploitasi hewan langka agar menimbulkan efek jera. Karya tulis ini ditujukan untuk mengevaluasi penegakan hukum terhadap tindak penganiayaan hewan dan ekspoitasi satwa langka di Indonesia. Penulisan artikel ini juga diharapkan dapat menyumbang kontribusi demi mewujudkan perlindungan kesejahteraan hewan dan kelestarian sumber daya alam hayati dimasa mendatang dengan menambah wawasan serta membangun kesadaran masyarakat, juga dapat menjadi kritik yang membangun terhadap hukum di Indonesia dan menjadi referensi pada penulisan-penulisan karya tulis ilmiah selanjutnya.

\section{Rumusan Masalah}

Dari uraian di atas, dapat diidentifikasikan masalah sebagai berikut : 
1. Bagaimana penegakan hukum terhadap pelaku penganiayaan hewan dan eksploitasi satwa langka di Indonesia?

2. Faktor apa saja yang menjadi penghambat proses penegakan hukum kasus penganiayaan hewan dan eksploitasi satwa langka di Indonesia?

\section{METODE PENELITIAN}

Penulisan artikel ini didasarkan pada metode penelitian hukum normatif yang berfokus pada pengumpulan data sekunder yang meliputi bahan hukum primer dan sekunder. Penelitian bersifat deskriptif dengan menggunakan pendekatan kualitatif untuk mendapatkan pemahaman terhadap gejala-gejala.

\section{HASIL DAN PEMBAHASAN}

\section{a. Penegakan Hukum terhadap Pelaku Penganiayaan Hewan dan Eksploitasi Satwa Langka di Indonesia}

Dalam rangka mengatasi tindakan penganiayaan dan eksploitasi hewan, perlu diatur pertanggungjawaban pidana untuk pelaku tindak pidana penganiayaan hewan. Di Indonesia, hukum yang mengatur hal tersebut terdapat dalam UU 14/2014 yang merupakan perubahan terhadap UU 18/2009 yang mengatur kesejahteraan hidup hewan yang berhubungan dengan praktek kekerasan, pengandangan atau perantaian. Hukum menganiaya binatang peliharaan dijelaskan dalam Pasal 91B UU 41/2014 yang menjelaskan bahwa orang yang menganiaya hewan sehingga mengakibatkan kecacatan pada hewan tersebut akan dijatuhkan pidana kurungan satu hingga enam bulan dan denda berkisar antara satu juta rupiah sampai lima juta rupiah. Pasal tersebut juga menyebutkan bahwa saksi yang melihat namun tidak melaporkan tindak penganiayaan terhadap hewan juga dapat diganjar pidana kurungan satu sampai tiga bulan dan denda berkisar antara satu juta rupiah sampai tiga juta rupiah.

Dalam Kitab Undang-Undang Hukum Pidana, hukum yang membahas mengenai perihal penganiayaan hewan terdapat dalam Pasal 302 yang mengancam tindakan menyakiti, melukai, maupun merugikan kesehatan hewan. Pelaku pelanggaran Pasal tersebut akan dipidana penjara selama maksimal tiga bulan, dan jika mengakibatkan kerugian hingga korban mengalami sakit lebih dari seminggu, cacat, luka berat, dan mati, ancaman pidana penjara yang dikenakan akan bertambah menjadi maksimal sembilan bulan. Selain itu juga terdapat Pasal 540 KUHP yang melarang masyarakat untuk menggunakan binatang untuk melakukan pekerjaan berat atau memanfaatkan binatang yang sedang berada dalam kondisi kurang optimal. Pelaku pelanggaran Pasal tersebut akan dikenakan sanksi berupa kurungan paling lama delapan hari dan denda paling banyak Rp2.250,00.

Sedangkan hukum yang membahas mengenai larangan eksploitasi satwa langka salah satunya yaitu UU 5/1990 tentang Konservasi Sumber Daya Alam Hayati dan Ekosistemnya. Selain itu, terdapat juga peraturan perundang-undangan lain yang berkaitan dengan perlindungan satwa langka. Peraturan perundang-undangan tersebut diantaranya PP 13/1994 tentang Perburuan Satwa Buru; PP 18/1994 tentang Pengusahaan Pariwisata Alam di Zona Pemanfaatan Taman Nasional, Taman Wisata Alam dan di Taman Hutan Raya; PP 68/1998 tentang Kawasan Suaka Alam dan Kawasan Pelestarian Alam; dan UU 16/2006 tentang sistem penyuluhan pertanian, perikanan dan kesehatan.

Terdapat 5 asas atau prinsip kesejahteraan hewan yang perlu diperhatikan dalam pertimbangan pembuatan legislasi mengenai perlindungan satwa yang dapat dijadikan pedoman oleh masyarakat dalam memelihara, mengelola, maupun memperlakukan binatang. Asas kesejahteraan hewan tersebut antara lain bebas dari rasa lapar, haus, dan malnutrisi; bebas dari rasa sakit dan tak nyaman; bebas dari rasa takut dan tertekan; bebas dari rasa sakit, luka dan penyakit; dan kebebasan mengekspresikan pola perilaku normal. Kelima asas tersebut harus 
dapat terpenuhi dalam kaitannya dengan pengelolaan dan perlakuan terhadap binatang. Individu maupun korporasi yang melanggar asas maupun peraturan perundang-undangan terhadap kesejahteraan hewan yang berlaku harus diberikan sanksi pidana yang menjerakan.

Meskipun terdapat hukum yang mengatur perihal penganiayaan dan eksploitasi hewan di Indonesia, permasalahan ini tetap menjadi permasalahan yang kerap kali terabaikan oleh para aparat penegak hukum. Pemanfaatan lumba-lumba sebagai hewan atraksi sebenarnya tidak dilarang selama lumba-lumba tersebut tidak mendapatkan perlakuan yang tidak seharusnya, dan hak-haknya masih terlindungi. Namun pada kenyataannya, banyak lumba-lumba yang diperlakukan dengan tidak pantas dan hidupnya semata-mata hanya dimanfaatkan untuk menjadi hiburan umat manusia. Banyak diantara mereka yang dididik dengan menggunakan kekerasan dan diletakkan dalam kolam berklorin yang membahayakan penglihatannya. Lumba-lumba yang cacat kemudian akan dipindahkan ke kolam dengan ukuran yang lebih kecil, jauh dari kelompoknya. Lingkungan yang tidak sesuai dengan habitat alaminya, keadaan terisolasi, serta kekerasan fisik oleh pelatih akan menimbun stress pada binatang tersebut dan berpotensi menyebabkan kematian dalam jangka panjang.

Seharusnya pemilik dari tempat penyedia jasa hiburan atraksi lumba-lumba tersebut dapat dikenakan sanksi pidana dari Pasal 91B UU 41/2014 atas cacat yang diakibatkan kepada hewan tersebut. Pemilik dan atau pelatih dari lumba-lumba tersebut juga telah melanggar Pasal 302 KUHP secara tidak langsung karena telah merugikan kesehatan hewan tersebut. UU 18/2009 mengenai Peternakan dan Kesehatan Hewan sendiri juga sudah mengatur tentang kesejahteraan hewan dalam Pasal 66 ayat (1) dan (2) yang mengatakan bahwa penangkapan, penanganan, dan pemeliharaan hewan harus dilaksanakan dengan sebaik-baiknya sehingga hewan dapat mengekspresikan insting naturalnya. Surat Kementerian Lingkungan Hidup dan Kehutanan (KLHK) Nomor: SP.041/HUMAS/PP/HMS.3/02/2020 yang memerintahkan pelarangan pertunjukan lumba-lumba keliling resmi dikeluarkan pada 6 Februari 2020. Namun pada kenyataannya belum ada ketegasan terhadap pelanggaran peraturan tersebut, karena pertunjukan sirkus hewan dianggap merupakan sebuah bentuk pendidikan.

Kejadian beberapa waktu lalu, di mana tersebar rekaman video seorang influencer bernama Lucinta Luna dan teman-temannya menunggangi lumba-lumba di sebuah Dolphin Lodge yang dianggap ilegal menuai kontroversi di media sosial (Kadafi, 2021). Izin dari tempat pertunjukan lumba-lumba tersebut sebenarnya sudah dicabut sejak setahun sebelumnya. Jadi, secara hukum, korporasi tersebut beroperasi secara ilegal. Korporasi tersebut kemudian hanya diberikan sanksi berupa pencabutan izin atau penutupan tempat usaha, sementara individu yang turut melakukan tindakan yang merupakan bentuk penganiayaan terhadap satwa yang dilindungi tersebut tidak mendapatkan sanksi. Selain daripada itu, juga terdapat kejanggalan mengenai tempat usaha yang seharusnya sudah ditutup namun masih dapat beroperasi. Terlihat bentuk ketidakprofesionalisme aparat penegak hukum dalam pemeriksaan pelaksanaan pencabutan izin korporasi.

Binatang darat yang dijadikan sebagai hewan atraksi dalam pertunjukan sirkus juga tak luput dari tindak penganiayaan oleh manusia. Mereka menghabiskan hampir seluruh hidup mereka dalam lingkup dengan ruang gerak yang terbatas. Agar pertunjukan dapat berlangsung, hewan sirkus dipaksa bergerak melebihi kemampuannya, seperti berdiri bertumpu kaki belakang, menyeimbangkan diri dengan satu kaki, dan sebagainya. Terkadang, pelatih dengan sengaja menyakiti kaki depan hewan berkaki empat seperti gajah dan singa agar mereka enggan menapak dengan kaki depan. Perlakuan ini menyiksa binatang-binatang tersebut dan berpotensi menimbulkan penyakit akibat stress dan luka fisik yang dialami oleh para satwa tersebut.

Kasus penyeretan anjing dari Curug sampai ke wilayah Kota Tanggerang juga berakhir tanpa keadilan bagi korban yang sudah tewas. Pihak aparat kepolisian yang menolak laporan hanya karena ketidakadaan bukti kepemilikan anjing menjadi cerminan atas lemahnya penegakan hukum di Indonesia saat ini terhadap hak-hak hewan. Jika ditinjau dari sisi hukum perundang- 
undangan yang berlaku di Indonesia, tindakan yang dilakukan oleh pelaku penganiayaan anjing tersebut telah melanggar Pasal 302 KUHP, UU Nomor 41 Tahun 2014, dan UU maupun peraturan pemerintah lainnya yang berhubungan dengan kesejahteraan hewan. Urgensi dari bukti kepemilikan hewan peliharaan tersebut perlu dipertanyakan. Apabila laporan atas penganiayaan hewan diwajibkan untuk menyertai bukti kepemilikan, apakah hewan peliharaan di Indonesia hanya dipandang sebagai barang?

Masih banyak kasus penganiayaan hewan lainnya, baik yang diberitakan maupun yang tersembunyi. Seperti kasus bleaching pada monyet yang terjadi bulan Juli 2021 lalu, penusukan mata kucing, penembakan orang utan, pembakaran anjing, dan lain sebagainya. Tidak ada satupun pelaku dari tindak pidana penganiayaan hewan tersebut yang diadili dengan seadiladilnya, bahkan beberapa berhasil lolos dari dakwaan.

Asia For Animals Coalition mencatat 1.626 dari 5.480 konten penyiksaan hewan di dunia yang tersebar di media sosial berlokasi di Indonesia, dan 1.569 diantaranya diunggah dari Indonesia (Fikrie, 2021). Dengan ini, Indonesia merenggut peringkat pertama dalam kategori negara penghasil konten penyiksaan hewan terbanyak di media sosial, dengan angka yang jauh mengungguli negara lainnya. Data ini mencerminkan moral bangsa yang rusak oleh penegakan hukum yang lemah.

Bulan September tahun 2020 lalu, tertangkap dua orang penjual kulit dan tulang harimau sumatera (Supardi, 2021). Berdasarkan UU 5/1990 dan P.106/MENLHK/SETJEN/KUM.1/12/2018 mengenai Jenis Tumbuhan dan Satwa yang Dilindungi, harimau sumatera merupakan jenis satwa liar dilindungi. Namun pada akhirnya, pelaku-pelaku tersebut hanya divonis dengan sanksi 7 bulan kurungan.

Terdapat sejumlah 24 ekor gajah yang mati di kantong Taman Nasional Tesso Nilo, Suaka Margasatwa Giam Siak Kecil dan Suaka Margasatwa Balai Raja, Riau dari tahun 2015 sampai awal tahun 2020 menurut data dari Yayasan Taman Nasional Tesso Nilo (YTNTN) (Mongabay, 2020). Kematian 24 ekor gajah tersebut mayoritas dikarenakan perburuan liar yang ditujukan untuk mengambil gadingnya untuk diperjualbelikan. Beberapa diantaranya terjerat, terkena tombak, diracun, juga ada yang mati terkena setrum dari pagar listrik akibat ulah manusia. Para pelaku perburuan tersebut kemudian ditangkap dan dipidana dengan hukuman tiga tahun penjara dan denda tiga juta rupiah, dengan subsider satu bulan kurungan apabila denda tersebut tak terlunaskan. Sanksi pidana dan denda yang diberikan tersebut dinilai sangat ringan jika dibandingkan dengan nilai gading dari salah satu satwa endemik yaitu gajah di Indonesia.

\section{b. Faktor-Faktor Penghambat Proses Penegakan Hukum Kasus Penganiayaan dan Eksploitasi Hewan}

1. Faktor Undang-Undang

Peraturan perundang-undangan yang membahas mengenai tindak pidana penganiayaan hewan secara umum cenderung menyertakan sanksi pidana yang tergolong ringan. Seperti pada kasus yang telah ditelaah sebelumnya, beberapa pelaku penganiayaan hewan dapat terbebas dari segala jerat pidana meskipun korban binatang yang teraniaya telah kehilangan nyawanya. Pelaku eksploitasi hewan langka yang merugikan angka satwa endemik negara juga mendapat jeratan hukuman yang sangat ringan dibanding dengan kisaran kerugian yang diakibatkannya. Apabila konstitusi dari suatu negara dinilai kurang mendukung pemberantasan suatu tindak pidana, maka masyarakat juga akan bersikap apatis terhadap permasalahan ini selama tidak ada yang merasa dirugikan.

4. Faktor penegak hukum

Kepribadian dari penegak hukum merupakan salah satu kunci dari kesuksesan proses penegakan hukum. Namun halangan yang sering dijumpai dalam penerapan di lapangan yang sebenarnya datang dari oknum penegak hukum itu sendiri. Masih banyak aparat 
penegak hukum yang memandang remeh tindak pidana yang berhubungan dengan pengusikan keanekaragaman hayati. Hal ini membuat berbagai kasus penganiayaan dan eksploitasi hewan tidak dapat tertangani dengan baik. Dalam hal ini, profesionalisme aparat penegak hukum perlu ditinjau ulang.

5. Faktor sarana dan fasilitas

Sarana dan fasilitas yang ada untuk menanggulangi kasus penganiayaan dan eksploitasi hewan di Indonesia dinilai kurang memadai. Hal ini mengakibatkan penghambatan pada proses penegakan hukum. Beberapa sarana dan fasilitas yang mempengaruhi proses penegakan hukum yaitu tenaga yang berpendidikan serta terampil juga peralatan yang mendukung pemberantasan tindak pidana tersebut.

6. Faktor masyarakat dan tradisi

Masyarakat menjadi peranan yang krusial dalam proses penegakan hukum, karena masyarakat adalah subyek hukum yang utama, dan pelaku tindak kejahatan penganiayaan hewan itu sendiri adalah bagian dari masyarakat. Kesadaran dan kepedulian dalam diri masyarakat sangat menentukan eksekusi dari suatu penegakan hukum. Masyarakat yang memandang sebelah mata kesejahteraan hewan cenderung melakukan hal-hal yang menguntungkan bagi dirinya sendiri, seperti pedagang yang menguliti binatang hidup-hidup (pithing) hanya demi mengantongi sejumlah pemasukan dari produk berbahan dasar hewan yang dijualnya. Beberapa daerah di Indonesia juga masih memberlakukan tradisi yang mengancam hak-hak hewan. Salah satunya yaitu tradisi karapan sapi madura yang pada zaman sekarang penyelenggaraannya tanpa memperhatikan sifat manusiawi, di mana sapisapi yang disertakan dalam karapan dioleskan rheumason di sekitar matanya, dan bokongnya dilukai menggunakan paku.

7. Faktor budaya hukum

Kompromi dalam menyelesaikan perkara pidana bukan hal yang jarang dilakukan masyarakat. Adanya anggapan bahwa tindak penganiayaan hewan adalah hal yang remeh dalam masyarakat membuat orang-orang yang mendapat kesenangan dari menyiksa makhluk hidup tidak segan untuk melakukan tindak asusila tersebut terhadap binatang yang dianggap inferior. Terdapat trend mengoleksi barang-barang 'unik' yang dalam pembuatannya menggunakan bagian-bagian tubuh dari satwa langka di antara masyarakat kelas atas. Terbentuk pemikiran bahwa menyiksa hewan bukanlah suatu tindak kejahatan yang besar karena pelaku dapat dengan mudah dibebaskan setelah berbincang-bincang dan meminta maaf dengan sejumlah uang ganti rugi. Budaya suap-menyuap diantara para aparat penegak hukum juga membuat pelaku tindak pidana dapat dengan mudah lolos dari suatu perkara setelah membujuk pihak polisi dengan sejumlah uang suap.

Dalam merealisasikan keadilan terhadap satwa di Indonesia, perlu dibuat suatu konstitusi yang mendukung penegakan hukum dan mengeliminasi tradisi-tradisi yang bertolak belakang asasasas kesejahteraan hewan. Dalam mengupayakan penegakan hukum yang maksimal, kepastian hukum sangat diperlukan. Kepastian hukum dapat diwujudkan dengan perumusan suatu peraturan perundang-undangan yang dapat dijadikan dasar hukum terhadap pidana mengenai penganiayaan hewan dan eksploitasi satwa langka sehingga tidak menimbulkan ambiguitas. Perumusan peraturan tersebut perlu dilaksanakan dengan sungguh-sungguh dengan bantuan para ahli di bidang yang bersangkutan, seperti ahli hukum dan ahli atau perwakilan dari perkumpulan pecinta hewan. Proses tersebut harus menyertai pertimbangan norma-norma yang berlaku di masyarakat dan ditunjang dengan asas kemanfaatan, sehingga peraturan tersebut dapat berlaku secara efektif dalam pemberantasan tindak pidana yang dimaksudkan.

Masyarakat yang bukan menjadi bagian dari golongan pecinta hewan akan mengacuhkan kesejahteraan hewan dalam setiap tindakan yang dilakukannya jika tidak ada pedoman hukum yang dapat membatasi perilakunya. Sanksi bagi pelaku penganiayaan dan eksploitasi hewan 
perlu diperberat untuk menimbulkan efek jera. Orang-orang yang melakukan transaksi pembelian barang maupun segala bentuk produk yang dihasilkan dari kegiatan eksploitasi satwa langka juga perlu dijerat pidana. Jalur damai tidak sepatutnya dinormalisasikan sehingga peraturan perundang-undangan tersebut dapat berfungsi secara efektif.

Jika masyarakat tidak dibekali edukasi perihal pentingnya keanekaragaman hayati dan hak-hak binatang sebagai makhluk hidup yang merasakan sakit, lapar, haus, dan stres, maka mereka akan menjadi bebal dan tidak suportif atas aksi penegakan hukum terhadap penganiayaan dan eksploitasi hewan langka. Makadari itu penyuluhan dan edukasi seperti penyelenggaraan seminar mengenai keanekaragaman hayati perlu digalakkan untuk membangkitkan kesadaran masyarakat. Meski begitu, walau ada golongan masyarakat yang menaruh kepedulian terhadap kesejahteraan satwa di Indonesia, mereka tidak memiliki kuasa untuk melakukan tindakan represif.

Perlu dibuat sistem pengawasan yang memadai terhadap pelatihan hewan sirkus sebagai salah satu persyaratan legalitas suatu korporasi yang bergerak di bidang bersangkutan. Aparat penegak hukum yang memiliki wewenang untuk menjerat seorang kriminal perlu menghadapi permasalahan ini secara tegas dan profesional. Aturan-aturan yang memberatkan pelapor untuk dapat memfinalisasi laporan penganiayaan hewan yang disaksikannya perlu ditiadakan. Aparat maupun badan kepolisian yang dinilai kurang serius dalam menyikapi tindak pidana tersebut perlu dilengserkan. Barangsiapa yang menerima suap dari pihak pelaku tindak pidana harus dijatuhkan sanksi pidana perihal kasus penyuapan. Supaya proses penyelidikan dapat berjalan dengan efektif, perlu disediakan sarana dan prasarana yang mendukung. Jika perlu, kantor kepolisian atau badan hukum yang dengan khusus dibuat untuk menangani permasalahan tersebut dapat dibangun.

\section{KESIMPULAN DAN SARAN}

Penegakan hukum terhadap pelaku tindak pidana penganiayaan hewan dan eksploitasi satwa langka di Indonesia masih kurang optimal. Kesejahteraan hewan peliharaan, hewan atraksi, dan satwa endemik pada kenyataannya kurang menjadi keprihatinan bagi para penegak hukum. Meskipun terdapat hukum yang mengatur pelarangan tindak penganiayaan hewan dan eksploitasi satwa yang terancam punah, pada realisasinya, belum ada ketegasan terhadap pelanggaran peraturan tersebut. Jarang ditemukan pelaku pelanggaran kesejahteraan hewan yang dijatuhkan hukuman yang maksimal berdasarkan peraturan yang berlaku. Banyak juga pihak yang diloloskan dari hukuman pidana sebab masih banyak orang, termasuk aparat penegak hukum yang menyepelekan tindak pidana tersebut. Pelaku pembunuhan hewan-hewan yang terancam punah yang mengambil bagian tubuhnya untuk dijual juga diberikan sanksi pidana yang sangat ringan jika dibandingkan dengan jumlah satwa endemik yang menurun akibat perbuatannya.

Hambatan proses penegakan hukum atas kasus penganiayaan dan eksploitasi hewan antara lain disebabkan kurang mendukungnya faktor peraturan perundang-undangan, penegak hukum, sarana dan fasilitas, serta kurangnya kesadaran masyarakat dan lemahnya budaya hukum. Agar tercipta keadilan terhadap hak hidup dan kesejahteraan hewan di Indonesia, perlu ada kepastian hukum dengan perumusan suatu peraturan perundang-undangan yang dapat dijadikan dasar hukum terhadap pidana mengenai penganiayaan hewan dan eksploitasi satwa langka secara keseluruhan, disertai dengan sanksi yang lebih menjerakan dan sesuai dengan kerugian yang ditimbulkan. Perlu dibuat sistem pengawasan yang memadai terhadap pelatihan hewan sirkus sebagai salah satu persyaratan legalitas suatu korporasi yang bergerak di bidang bersangkutan. Edukasi dan penyuluhan mengenai permasalahan ini juga perlu digalakkan. Selain itu, keseriusan dan kesungguhan aparat kepolisian dalam menangani kasus mengenai perihal tersebut perlu ditingkatkan diikuti dengan pemberian sanksi pencabutan jabatan bagi yang dianggap gagal 
dalam melaksanakan tugasnya. Supaya proses penyelidikan dapat berjalan dengan efektif, sarana dan prasarana yang mendukung juga harus difasilitasi.

\section{Ucapan Terima Kasih}

Dengan selesainya penyusunan artikel ini, penulis menyampaikan terima kasih kepada :

1. Bapak Yuwono Prianto, S.H, M.H selaku dosen mata kuliah Pengantar Hukum yang selalu bersedia meluangkan waktu serta ikut menuangkan pikiran dan tenaganya dalam membimbing penulis sehingga artikel ini dapat terselesaikan dengan baik.

2. Keluarga para penulis, yang memberikan dukungan baik moral, spiritual maupun material hingga artikel ini dapat terselesaikan.

\section{REFERENSI}

Alim, M. 2019. “Karapan Sapi Madura: Tradisi atau Penyiksaan Hewan?”. https://etnis.id/karapan-sapi-madura-tradisi-atau-penyiksaan-hewan/. Diakses tanggal 7 September 2021 pukul 16:53.

Aries, A. 2013. "Perbuatan Melawan Hukum Dalam Hukum Perdata dan Hukum Pidana". https://www.hukumonline.com/klinik/detail/ulasan/lt5142a15699512/perbuatan-melawanhukum-dalam-hukum-perdata-dan-hukum-pidana/. Diakses tanggal 3 September 2021 pukul 21:01.

Claudia, L. V. 2018. "Lumba-lumba Terus Dipaksa Menari Meski Ditentang Bertubi-tubi". https://kumparan.com/kumparannews/lumba-lumba-terus-dipaksa-menari-meski-ditentangbertubi-tubi-1541046400475192375/full. Diakses tanggal 2 Oktober pukul 23:30.

Evan. 2019. "Pidana Penjara Pelaku Perdagangan Satwa Liar Melalui Medsos". http://ksdae.menlhk.go.id/info/5959/pidana-penjara-pelaku-perdagangan-satwa-liarmelalui-medsos.html. Diakses tanggal 2 Oktober 2021 pukul 23:01.

Fanny, V. dan Redi Ahmad. 2018. "Perlindungan Lumba-lumba Sebagai Satwa Langka yang Dilindungi Dari Tindakan Penempatan dan Atraksi Hiburan yang tidak Sesuai”. Jurnal Hukum Adigama. 01(01), 3-4.

Fikrie, M. 2021. "Indonesia Posisi Pertama Sumber Video Penyiksaan Hewan di Medsos". https://kumparan.com/kumparantech/indonesia-posisi-pertama-sumber-video-penyiksaanhewan-di-medsos-1wPDxv2bhPX/3. Diakses tanggal 3 September 2021 pukul 21:30.

Fitriani, R. 2018. "Pertanggungjawaban Pidana Terhadap Pelaku Tindak Pidana Penganiayaan Hewan". Palembang: Universitas Sriwijaya.

Handoko, D. (2018). Kitab Undang-Undang Hukum Pidana. Hawa dan AHWA, Pekanbaru.

Kadafi, M. 2021. "Dolphin Lodge Tempat Lucinta Luna Tunggangi Lumba-lumba Diduga Ilegal". https://www.merdeka.com/peristiwa/dolphin-lodge-tempat-lucinta-luna-tunggangilumba-lumba-diduga-ilegal.html. Diakses tanggal 3 September 2021 pukul 21:51.

Kurniawati, E. 2021. "Penganiayaan Hewan, Kucing Diinjak Hingga Mati Karena Buang Air Sembarangan". https://metro.tempo.co/read/1444668/penganiayaan-hewan-kucing-diinjakhingga-mati-karena-buang-air-sembarangan/full\&view=ok. Diakses tanggal 3 September 2021 pukul 21:53.

Lana, D. P. D. 2019. "Penegakan Hukum Terhadap Pelaku Perdagangan Satwa Langka Berdasarkan Hukum Pidana".

Liuw, Y. 2015. "Perlindungan Hukum terhadap Hewan Lindung Menurut Undang-Undang Nomor 5 Tahun 1990". Lex Crimen, 04(03), 24-25.

Marwasih, T. 2016. "Penegakan Hukum Terhadap Penyiksaan Lumba-lumba dalam Peragaan Atraksi Satwa oleh Korporasi di Indonesia”. Sumedang : Universitas Padjadjaran. 
Mongabay. 2020. "Para Pemburu Gading Gajah Riau". https://www.mongabay.co.id/2020/10/27/para-pemburu-gading-gajah-riau/. Diakses tanggal 3 September 2021 pukul 22:00.

Naufal, M. 2021. "Fakta-fakta Kasus Anjing Diseret Pengendara Motor, Hewan Curian hingga Laporan Ditolak Polisi”. https://megapolitan.kompas.com/read/2021/02/02/09081601/fakta-fakta-kasus-anjingdiseret-pengendara-motor-hewan-curian-hingga. Diakses tanggal 22 Agustus 2021 pukul 15.30

Nurjanah, E. 2016. "Demi Produk Mewah, Buaya dikuliti Hidup-Hidup secara Pithing". https://www.liputan6.com/citizen6/read/2688255/demi-produk-mewah-buaya-dikulitihidup-hidup-secara-pithing. Diakses tanggal 23 Agustus 2021 pukul 14:22.

Rachmawati, 2019. "7 Kasus Penyiksaan Satwa, Mata Kucing Ditusuk hingga Orangutan Terluka dengan 73 Peluru". https://regional.kompas.com/read/2019/12/18/06160021/7kasus-penyiksaan-satwa-mata-kucing-ditusuk-hingga-orangutan-terluka-dengan. Diakses tanggal 3 September 2021 pukul 22:03.

Republik Indonesia. 2014. Undang-undang (UU) tentang Perubahan atas Undang-Undang Nomor 18 Tahun 2009 Tentang Peternakan dan Kesehatan Hewan. Jakarta: Badan Pemeriksa Keuangan.

Republik Indonesia. 1990. Undang-undang (UU) Nomor 5 Tahun 1990 tentang Konservsi Sumber Daya Alam Hayati dan Ekosistemnya. Jakarta: Badan Pemeriksa Keuangan.

Republik Indonesia. Kitab Undang-Undang Hukum Pidana. Mahkamah Agung. https://jdih.mahkamahagung.go.id/index.php/hukum-acara/4.-Hukum-Acara/KitabUndang-Undang-Hukum/.

R Fitriani. et, al. 2018. "Pertanggungjawaban Pidana Terhadap Pelaku Tindak Pidana Penganiayaan

Hewan". https://scholar.google.com/scholar?hl=id\&as_sdt=0\%2C5\&q=Khasus+penganiayaan+hew an\&btnG=\#d=gs_qabs\&u=\%23p\%3D9z0LAz138hUJ. Diakses tanggal 20 Agustus 2021 pukul 21:11.

Saptoyo, R. D. A. 2021. "Ramai Bleaching pada Monyet, Ada Unsur Paksaan dan Penyiksaan”. https://www.kompas.com/tren/read/2021/07/14/121100365/ramai-bleaching-pada-monyetada-unsur-paksaan-dan-penyiksaan. Diakses tanggal 3 September 2021 pukul 22:16.

Saras, S. 2018. "Penegakan Hukum oleh Kepolisian terhadap Tindak Pidana Penganiayaan Hewan (Studi pada Polres Lampung Tengah)". Jurnal Poenale, 06(05), 1-3.

Sianturi, H. R. E. 2018. "Pemidanaan terhadap Pelaku Perdagangan Hewan Langka Menurut Hukum Pidana Positif". Lex Crimen, VIII(2), 37-38.

Strawan, G. A. 2021. "Peran Hukum Perlindungan Konsumen Dalam Menindaklanjuti Kuliner Extrim Berupa Satwa Liar Di Masa Pandemi Covid-19”. Jurnal Media Komunikasi Pendidikan Pancasila dan Kewarganegaraan, 03(02), 104.

Supardi, A. 2021. "Penjual Kulit dan Tulang Harimau Sumatera di Bengkulu Ditangkap". https://www.mongabay.co.id/2021/06/23/penjual-kulit-dan-tulang-harimau-sumatera-dibengkulu-ditangkap/. Diakses tanggal 24 Agustus 2021 pukul 20:03.

Tania, L. 2019. "Penegakan Hukum Bagi Pelaku Penganiayaan Hewan". Lex Administratum, 05(02), 2-17.

Wiradana, INA. dan Anak Agung Sagung Wiratni Darmadi. 2015. "Tindak Pidana Asusila Terhadap Hewan Ditinjau Dari Perspektif Hukum Pidana”. Journal Ilmu Hukum, 05(02), $1-3$.

Zali, M. (2018). "Critics for violating animal welfare in the cruel side of culture: indonesian perspectives”. Adv. Anim. Vet. Sci, 6(9), 372-379. 